\title{
DEVELOPMENT OF A NEW TYPE OF FINNED HEAT EXCHANGER
}

\author{
Mladen Bošnjaković, Ante Čikić, Simon Muhič, Marinko Stojkov
}

Original scientific paper

A new geometric form of fins (needle fins) for finned heat exchangers of gas-liquid type is described. It achieves a higher heat transfer coefficient and lower mass of the heat exchange surface relative to the heat exchangers with circular fins which in this case served as a basis for comparison. For the analysis of the heat transfer, the computational fluid dynamics analysis with ANSYS Fluent software was applied. Numerical simulation was performed for the round fins and fins with a new, innovative geometric shape at air flow speeds of $1 \mathrm{~m} / \mathrm{s}$ to $5 \mathrm{~m} / \mathrm{s}$. The results of numerical simulations, with regard to the exchanged heat and pressure drop were verified by the correlations available in the literature and compared to the simulation results for tubes with innovative fins. Results show an increase in the amount of $N u$ from $20 \%$ to $30 \%$ for $2300>\operatorname{Re}>12000$ while reducing mass of heat exchange surfaces of $23,8 \%$.

Keywords: finned heat exchanger; heat exchange; heat exchanger efficiency; needle fins; numerical simulation

\section{Razvoj novog tipa lamelnog izmjenjivača topline}

Izvorni znanstveni članak Opisan je novi geometrijski oblik lamele (igličaste lamele) za orebrene cijevne izmjenjivače topline plin - tekućina pomoću kojeg se postiže veći koeficijent prijelaza topline, a time i manja masa izmjenjivačkih površina u odnosu na izmjenjivače topline s okruglim lamelama koji su u ovom slučaju poslužili kao baza za usporedbu. Za analizu izmjene topline i pada tlaka primijenjena je računalna dinamika fluida s programom ANSYS Fluent. Numerička simulacija provedena je za slučaj zagrijavanja zraka koji struji oko cijevi s lamelama novog geometrijskog oblika te oko cijevi s lamelama konvencionalnog kružnog oblika brzinama od $1 \mathrm{~m} / \mathrm{s}$ do $5 \mathrm{~m} / \mathrm{s}$. Rezultati numeričke simulacije obzirom na izmijenjenu toplinu i pad tlaka za cijevi s okruglim lamelama provjereni su pomoću korelacija dostupnih u literaturi te su uspoređeni s rezultatima simulacije za cijevi s inovativnim lamelama. Rezultati pokazuju povećanje iznosa $N u$ značajke od $20 \%$ do $30 \%$ za $2300>R e>12000$ uz smanjenje mase izmjenjivačkih površina od $23,8 \%$.

Ključne riječi: efikasnost izmjenjivača topline; igličaste lamele; lamelni izmjenjivač topline; numerička simulacija; prijelaz topline

\section{Introduction}

Heat exchangers are used in different technical areas and very often in energy and thermal engineering, petroleum, chemical, food, automotive industry and in various processes where heat exchange is required. Caused by intensity of heat change and the adaptable construction and fabrication, finned tube exchangers with circular fins are often used. In finned tube exchangers, heating fluid is usually flowing through the tubes and the gas flow across finned tubes in staggered or in-line configuration. Heat transfer resistance on the gas side makes $80 \%$ of the total heat transfer resistance, so determining the improvement of the heat transfer on the gas side for different cases is a significant contribution to increasing the effectiveness of the finned heat exchangers.

Increased heat exchange can be achieved by increasing the heat transfer surface, increasing the heat transfer coefficient, or increasing the thermal efficiency of the finned surface. The increase in the exchange surface directly increases the cost of the material, which may amount to up to $80 \%$ of the total price of the exchanger, so researches are focused on the other two parameters that are interconnected.

Increase in the heat transfer coefficient can be achieved by applying different fins shapes that increase the turbulence of the flow, so the thermal boundary layer is periodically interrupted which results in more efficient heat exchange. However, the innovative design of fins with the increase in the heat transfer coefficient causes increase of pressure drop in the gas flow across tube bundle or increases the fan power to transport the gas through the heat exchanger.
In practical application, weight and size of the heat exchanger are often very important and contribute to proper and economical functioning of unit or the entire system (e.g., the space for car access is limited). However, the mass of the heat exchanger is also very important (less mass means less total car mass and lower fuel consumption).

\subsection{Literature review}

The analytical approach to solving heat transfer for simple geometry of finned surfaces dates from the last century when basic functions were defined for temperature profiles and fin efficiency for different fin shapes. Hashizume et al. [1] analysed the thermal efficiency of rectangular cross sectional circular fins and performed an analytical solution in the form of a modified Bessel function.

Kays and London [2] provided experimental correlations for a wide range of configurations adopted in compact extended surface heat exchangers and presented test data on finned circular tubes.

Ward and Young [3] developed heat transfer and pressure drop correlations for plain finned tubes with triangular pitch. They compared their pressure drop data with a correlation from literature.

Kearney and Jacobi [4] investigated experimentally local heat transfer behaviour in staggered and in-line arrangements with the help of optical adaptation of the naphthalene sublimation technique in order to evaluate the analytical fin efficiency.

Experimental investigations of round (solid) and serrated

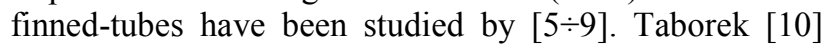
and Frasz [6] compared the varying influences of round 
and segmented fins. Weierman [11] investigated the performance of in-line and staggered tube arrangement of segmented finned tubes.

For crossflow over finned tube banks, a fairly large set of experimental data can be found in the Russian literature (Zhukauskas, [12]) and the recommended correlations for tubes with circular and helical fins.

Stasiulevicius et al. [13] developed correlations of the convective heat transfer coefficient and resistance of finned-tube bundles in a cross flow including the effects of geometric parameters of fins and tube arrangement within the bundle. Mon and Gross [14] investigated the effects of the fin spacing on four-row round-finned tube bundles in staggered and in-line arrangements by three dimensional numerical study.

Ali Shakir Al-Jaberi et al. [15] performed experiments on circular fins with slanted blades attached on the copper tube surface in order to reduce the thermal boundary layer. They examined effects of number of slanted blades and Reynolds number on the heat transfer characteristics. Results show $20 \%$ to $27,5 \%$ higher Nusselt number for slanted fins than for circular fins, but they did not examine pressure drop in tube bundle.

A. Lemouedda et al. [16] presented the results of numerical calculations of spiral finned tubes and compared them with the results for bare tubes. Naess [17] experimentally tested heat transfer and pressure drop for L-fins and in this case gave correlations for heat transfer and pressure drop.

Martinez at al. [18] conducted a comparative study of heat transfer and pressure drop for spiral serrated fins. Cléirigh and Smith [19] studied three spiral shapes of fins: full fin; partially segmented and fully segmented.

B. Anoop, C. Balaji, and K. Velusamy [20] investigated the heat transfer on one tube with serrated fins combining experimental approach and numerical calculation. The depth of the segment, the pitch of the fins, fin height and thickness were investigated.

Rene Hofmann et al. [10] experimentally investigated heat exchanger with finned tubes in order to optimize it. $\mathrm{U}$ and $\mathrm{L}$ shaped fins were full and serrated. Fin height, thickness, fin spacing and the width of the fin segment were varied. They found an average increase in Nusselt's number by $22 \%$ when using serrated fins.

The complex turbulent flow pattern across the fin and tube surface made the theoretical prediction of pressure drop very difficult and therefore most of the published correlations were related to the experiments. All of them use the fluid velocity at the minimum flow area of tube bundle. One group of correlations is based on tube outside diameter $\left(d_{0}\right)$ or fin collar diameter as the characteristic length for calculations of Re and $\mathrm{Nu}$ number.

Widely cited correlations for pressure drop are authorized by Briggs and Young [22], ESDU [35], Schmidt [23], Ward and Young [24] and Nir [25].

Numerous methods used in computational fluid dynamics have been developed today. A review of all the methods applied today in computer fluid dynamics was given by Md Lokman Hosain and Rebei Bel Fdhil [26]. Hossain Nemati and Mohammad Moghimi [27] analysed the influence of choice of different models of turbulence at the flow simulation in a four-row tubular tube bundle. Detailed analysis shows that computational fluid dynamics can be used as a flow visualization tool. Due to certain deviations in the results between certain models it is necessary to compare the results with experimental research.

\section{Research object, material and method}

The geometric model of the tubular heat exchanger on which its thermal efficiency and thermal effectiveness will be estimated in relation to the reference model, consists of an insulated casing inside which is a bundle of tubes with needle shaped fins. Water as a heating medium is introduced into the inlet chamber, passes through the tubes and goes to the outlet chamber. Across the finned tubes flows colder air. The new and innovative shape of the needle-shaped fins enables achievement of higher turbulence levels of the fluid flowing around the fins, and thus higher heat exchange.

\subsection{Physical model of heat exchanger with needle-shaped fins}

For research implementation, the tube $\varnothing 20 \times 1,5$ is selected. As a reference geometry, a round fin $\varnothing 40 / \varnothing 20$ with thickness $0,5 \mathrm{~mm}$ was selected (Fig. 1a). The new needle type fin is shown in Fig. $1 \mathrm{~b}$ and has eight vertices spaced uniformly along the circumference.

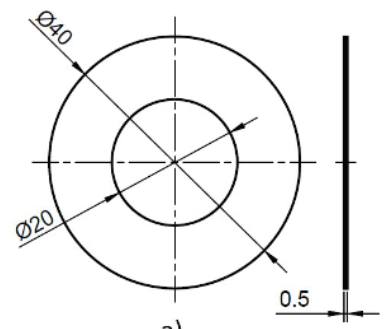

a)

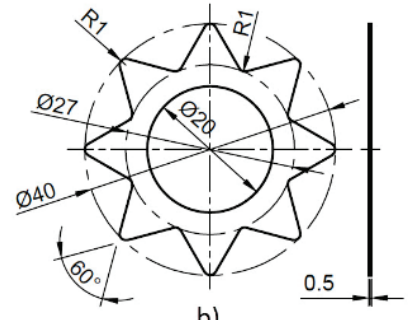

b)
Figure 1 Geometry of round fin and needle type fin

Different materials are used for making heat exchangers. Steel, copper and aluminium are the most common. For the implementation of comprehensive research, the selected material of the tubes and fins is stainless steel. Stainless steel is selected because of a wider range of application, higher temperature resistance, resistance to corrosion and resistance to fouling, and facility to easy clean the fin surface even though it has smaller heat conductivity coefficient than aluminium and copper.

Initial diameter, thickness and pitch of the fins were selected according to the recommendations of the authors dealing with the problem of finned tubular heat exchangers $[4,12,13,14,22,28,29,30,31]$.

\subsection{Numerical analysis}

The numerical analysis is focused on air flow across tubes because the air side resistance of the heat exchange makes up $80 \%$ of the total resistance to the heat exchange.

Certain assumptions and simplifications were adopted for the mathematical description of the thermal phenomena within the heat exchanger. 
The most common assumption that is applied when defining fluid flow is fluid continuity. The characteristic dimensions of the analysed innovative exchanger are large enough and the conditions of the continuum hypothesis are fulfilled.

The assumptions of homogeneity and isotropy were also introduced. Homogeneity implies that the physical properties of the substance are the same at all points. Thus, the air is considered a homogeneous mixture of gases because the proportion of individual gases that compose the air is equal at all points of the fluid. Isotropy implies that the physical properties of the observed substance are the same in all directions. It is assumed that the thermal conductivity of the fin is equal in all directions, though, for example, the fin composed of different materials layers does not have the same thermal conductivity in the layer direction and in the direction normal to the layer.

Air is considered as homogeneous mixture of gases and is treated as a one-component fluid (dry air). There is no fluid leakage through the walls of the finned exchanger and the heat exchange with the environment is negligible. The fins are completely and tightly attached to the tube and there is no contact resistance between the tube and the fin surface. Steady state analysis is performed.

The numerical domain was chosen to perform the numerical analysis of the tube heat exchanger. For a heat exchanger with a uniform fluid flow field at the inlet, a typical repeating section in the heat exchanger is selected for the domain (Fig. 2), and the solutions obtained are assumed valid for the entire heat exchanger.
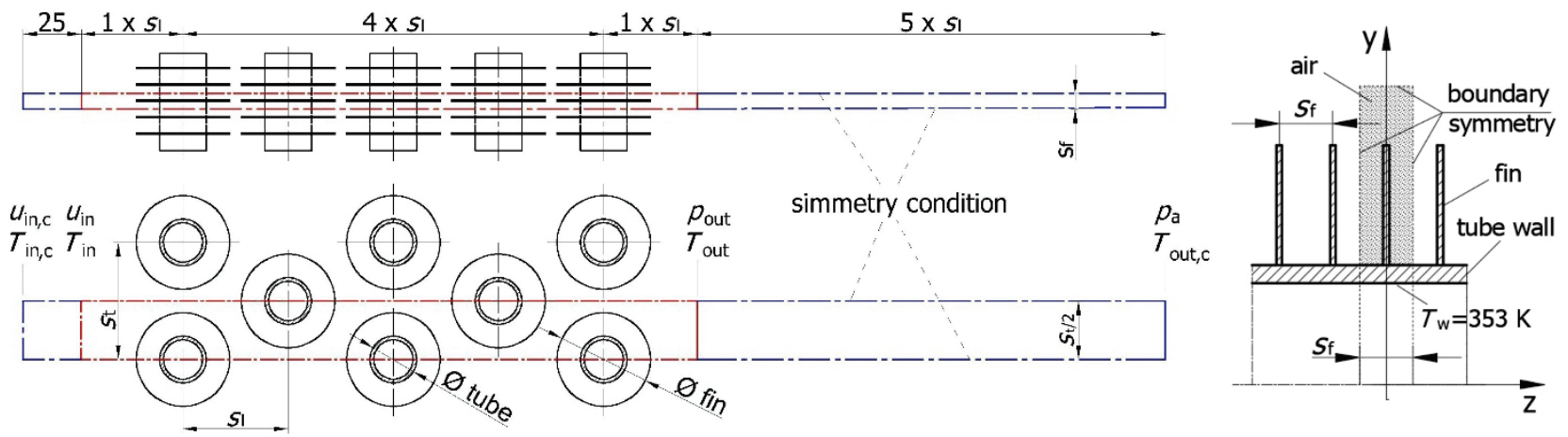

Figure 2 Mathematical model of computational domains

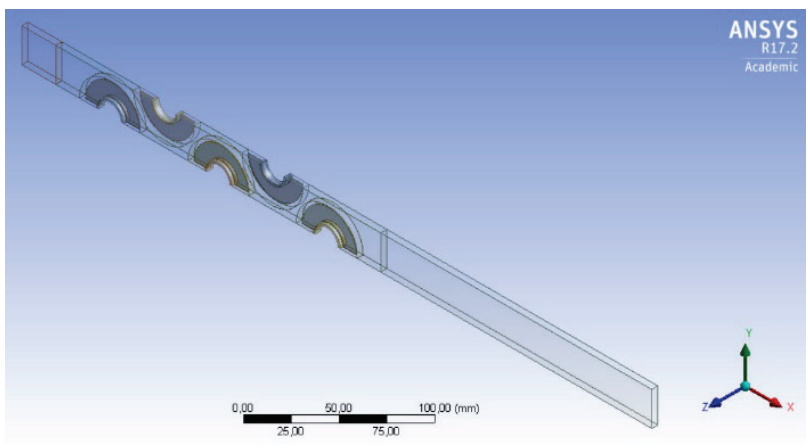

Figure 3 3D model of computational domain

Boundary and initial conditions are determined when defining the computational model and the physical properties of fluids and materials of the exchange surfaces.

Boundary and initial conditions include defining:

- The air entering the computational domain is assumed to have uniform velocity over the cross section and ranges from $1 \mathrm{~m} / \mathrm{s}$ to $5 \mathrm{~m} / \mathrm{s}$, and turbulence intensity 5 $\%$.

- The air temperature at the inlet to the heat exchanger is $288 \mathrm{~K}$.

- Hot water at the inlet to tubes has temperature $353 \mathrm{~K}$. Because water has a high thermal capacity, it is assumed that the temperature of the tube inner wall is constant and equal to the water temperature.

- At the sides of the computational domain it is set symmetry boundary condition.
- The gauge pressure $p_{\text {out,c }}$ at the outlet of channel is set to zero. This corresponds to atmospheric conditions $p_{\mathrm{a}}$.

- Hydraulically smooth walls were defined for outer tube and the fin walls.

- Symmetry condition is set for top, bottom, left and right side of computational domain. Symmetry condition is applied due to simplifying the calculation where it is possible to reduce computational domain. The basic requirement is that the geometry is symmetric and also that the expected solution of the temperature field and the fluid flow fields are symmetric. At the symmetry planes a zero heat flux is assumed. The normal velocity component at the symmetry plane equals zero, i.e. no convective flux across that symmetry plane exists. Thus, the temperature gradients and tangential components of the velocity gradients in normal direction are set to zero.

- Physical properties of air are defined as polynomial function of temperature (and pressure) and thus set in Ansys Fluent software. Density of the air is based on incompressible ideal gas law.

- The physical properties of the fin and tube material are set constant $\left(\lambda_{\mathrm{t}}=16,2 \mathrm{~W} /(\mathrm{m} \cdot \mathrm{K}), \rho_{\mathrm{t}}=7860 \mathrm{~kg} / \mathrm{m}^{3}\right)$.

\subsection{Properties of materials}

The definition of physical properties of used materials includes the determination of thermal conductivity, dynamic viscosity, density, specific heat capacity of fluid flowing across the tube bundle (dry air) 
and the material of the fins and tubes. The material of the tubes and fins is stainless steel, the surfaces are clean without any additional heat resistance.

The calculation of non-dimensional numbers $R e, N u$, $\operatorname{Pr}$ and $E u$ is based on the physical properties of the working fluid (air) that are generally dependent on temperature and pressure. For a precise calculation of the above non-dimensional features it is necessary to clearly define the temperature at which the physical properties of the fluid are taken. The fluid temperature in the thermal boundary layer varies from $T_{\mathrm{w}}$ at the surface to freestream temperatures at the outer edge of the boundary. The fluid properties also vary with temperature, and thus with position across the boundary layer. In order to account for the variation of the properties with temperature, the fluid properties are usually evaluated at the so-called film temperature, defined as

$T_{\mathrm{bl}}=\left(T_{\mathrm{w}}+T_{\mathrm{av}}\right) / 2$

which is the arithmetic average of the surface and the average free-stream temperatures. Average free-stream temperature is defined as

$T_{\mathrm{av}}=\left(T_{\text {in }}+T_{\text {out }}\right) / 2$

The fluid properties are then assumed to remain constant at those values during the entire flow.

An alternative way of accounting for the variation of properties with temperature is to evaluate all properties at the average free stream temperature $T_{\mathrm{av}}$ and to multiply the Nusselt number relation by $\left(P r_{\mathrm{av}} / P r_{\mathrm{w}}\right)^{r}$ or $\left(\mu_{\mathrm{av}} / \mu_{\mathrm{w}}\right)^{r}$, where $r$ is appropriate coefficient [32].

In this paper, the temperature of the tube outer wall is assumed approximately equal to the inner wall temperature.

Reynolds number (Eq. 3) is a measure of the relative importance between the momentum flux by advection and by diffusion in the same direction. It is important that velocity $\left(u_{\mathrm{ff}}\right)$ and length $(L)$ are taken in the same direction. For calculating the Reynolds number, the physical properties (density, dynamic viscosity) are taken at mean air temperature $T_{\mathrm{av}}$. Characteristic dimension $(L)$ is based on the outer diameter of the tube $\left(d_{0}\right)$, and the mass flux, i.e. velocity through the narrowest free flow area within the tube bundle. This is consistent with the relevant literature

$$
R e=\frac{\rho_{\mathrm{av}} \cdot u_{\mathrm{ff}} \cdot L}{\mu_{\mathrm{av}}}=\frac{\dot{\mathrm{m}} \cdot \mathrm{d}_{0}}{\mu_{\mathrm{av}}}
$$

For the geometries considered in the present study, the narrowest free flow area is the area between two tubes in the transversal direction, and can be defined as

$$
A_{\mathrm{ff}}=s_{\mathrm{f}} \cdot\left(s_{1}-d_{0}\right)-2 \cdot h_{\mathrm{f}} \cdot t_{\mathrm{f}}
$$

For heat transfer correlations, the Nusselt number $(N u)$ is defined as

$$
N u=\frac{\alpha_{0} \cdot d_{0}}{\lambda_{\mathrm{bl}}}
$$

where $\alpha_{0}$ is actual average gas-side heat transfer coefficient.

For pressure drop correlations, the Euler number $(E u)$ is defined as

$$
E u=\frac{\Delta p}{N_{1} \cdot \rho_{\mathrm{av}} \cdot u_{\mathrm{ff}}^{2}}
$$

\subsection{Governing equations}

The mathematical model used to describe a physical problem is a set of differential equations and constitutive relations and initial and boundary conditions. The basic equations of fluid dynamics are derived from:

Conservation of Mass:

$\frac{\partial \rho}{\partial t}+\frac{\partial\left(\rho u_{\mathrm{j}}\right)}{\partial x_{\mathrm{j}}}=0$

Conservation of Momentum:

$$
\frac{\partial\left(\rho u_{\mathrm{j}}\right)}{\partial t}+\frac{\partial\left(\rho u_{\mathrm{j}} u_{\mathrm{i}}\right)}{\partial x_{\mathrm{j}}}=\rho f_{\mathrm{i}}+\frac{\partial \sigma_{\mathrm{ji}}}{\partial x_{\mathrm{j}}}
$$

Conservation of Energy:

$\frac{\partial(\rho e)}{\partial t}+\frac{\partial\left(\rho e u_{\mathrm{j}}\right)}{\partial x_{\mathrm{j}}}=-\rho f_{\mathrm{i}} u_{\mathrm{i}}+\frac{\partial\left(\sigma_{\mathrm{ji}} u_{\mathrm{i}}\right)}{\partial x_{\mathrm{j}}}-\frac{\partial q_{\mathrm{j}}}{\partial x_{\mathrm{j}}}$

The established mathematical model is solved by using the finite volume method that is based on dividing the computational domain into small volumes and integration of equations of conservation at these volumes thus obtaining a system of discrete algebraic equations that are then solved iterative. Computational domain is meshed by ANSYS software.

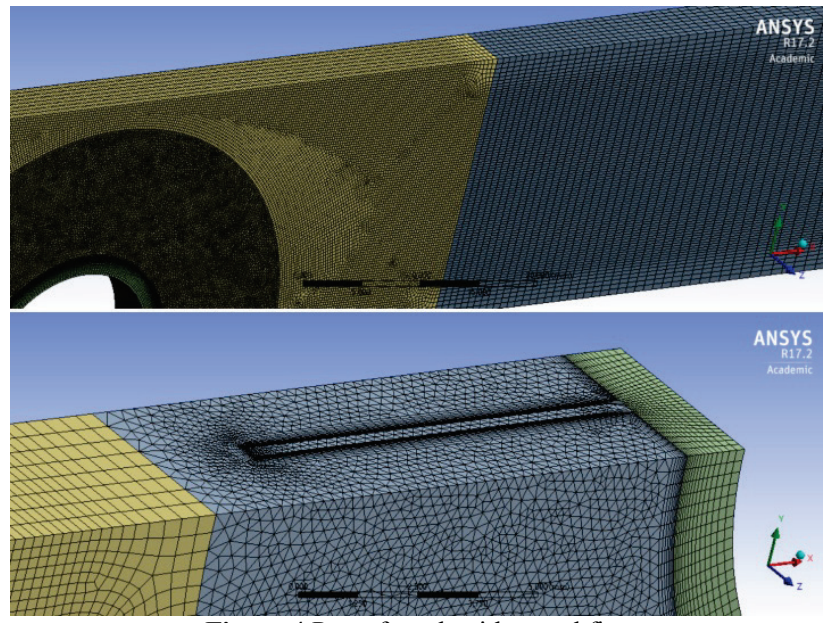

Figure 4 Part of mesh with round fins

Meshing was performed by using a hybrid mesh where most of the volume is structured mesh, and the 
smaller part around the fins is unstructured mesh. The area along the fins and tubes where the convection heat transfer is performed is covered with eight boundary layers and the thickness of the first layer is $0,025 \mathrm{~mm}$ (Fig. 4). By successive refining of the mesh, we found the solution, independent of the computational mesh. In the final analysis we used the mesh with 10,9 million of the finite volumes (elements).

Numerical calculation was performed with ANSYS Fluent software. A steady state model of heat exchange is assumed. Two models of turbulence were used: $\mathrm{k}-\varepsilon$ Realizable with Enhanced Wall Treatment (EWT) method and k- $\omega$ SST. The calculation results of both models were used for the computation of $N u$ and $E u$, which were compared with the results of the literature with the aim of selecting a turbulence model whose results coincide more with the results of the literature.

\subsection{Solution methods and convergence of the solution}

An important aspect when performing numerical simulations is to judge whether the simulation is complete and converged, or not. There are several different ways to check this and ensure convergence. The most used method is to look at the residuals for each variable being solved. In ANSYS Fluent software the default convergence criterion is defined using globally scaled residuals. The default convergence criterion in ANSYS Fluent states that needs to be reduced to $10^{-3}$ for all solved equations, except the energy equation for which the criterion is set to $10^{-6}$. Scaled residuals may not give the full picture. A good indicator to judge convergence is to look at how the residuals develop with the iterations. A good indication that convergence is reached is if the residuals continue to decrease or remain low for several iterations. Overview of solution methods and convergence criteria is visible in Tab. 1.

Table 1 Solutions methods and convergence criteria

\begin{tabular}{|l|l|}
\hline \multicolumn{1}{|c|}{ Item } & \multicolumn{1}{|c|}{$\begin{array}{c}\text { Solutions methods } / \\
\text { convergence criterion }\end{array}$} \\
\hline Pressure velocity coupling & SIMPLE \\
\hline Momentum & Second order upwind \\
\hline Turbulent kinetic energy & Second order upwind \\
\hline Turbulent dissipation rate & Second order upwind \\
\hline $\begin{array}{l}\text { Convergence judgement } \\
\text { conditions }\end{array}$ & $\begin{array}{l}\text { Continuity, } k, \omega, \text { velocity for } x, \\
y, z: 1 \times 10^{-4} \\
\text { Energy: } 1 \times 10^{-9}\end{array}$ \\
\hline
\end{tabular}

Solution is converged after about 11000 iterations.

The convergence error is verified on the amount of heat delivered by the inner wall of the tube through the outer surface of the tube and the fins and the amount of heat received by the air. The maximum deviation is $0,077 \%$.

\section{The results of numerical calculation 3.1 The results for round fins}

The input and output data of the heat calculations are summarized in the tables below.

For the calculation of the necessary flow variables at boundaries (for example at inlet and outlet of tube bundle), mass flow averaging was used.
Table 2 Characteristic dimensions of tube and fins

\begin{tabular}{|l|c|c|c|}
\hline Tube and fin material & - & - & Stainless steel \\
\hline Tube outside diameter & $d_{0}$ & $\mathrm{~mm}$ & 20 \\
\hline Tube inside diameter & $d_{\mathrm{i}}$ & $\mathrm{mm}$ & 17 \\
\hline Tube rows configuration & - & - & staggered \\
\hline Transverse tube pitch & $s_{\mathrm{t}}$ & $\mathrm{mm}$ & 50 \\
\hline Longitudinal tube pitch & $s_{1}$ & $\mathrm{~mm}$ & 40 \\
\hline Fin height & $h_{\mathrm{f}}$ & $\mathrm{mm}$ & 10 \\
\hline Fin thickness & $t_{\mathrm{f}}$ & $\mathrm{mm}$ & 0,5 \\
\hline Fin pitch & $s_{\mathrm{f}}$ & $\mathrm{mm}$ & 4,5 \\
\hline Number of rows & $N_{1}$ & - & 5 \\
\hline
\end{tabular}

Table 3 Boundary conditions

\begin{tabular}{|l|c|c|c|}
\hline Inlet air temperature & $T_{\mathrm{in}, \mathrm{c}}$ & $\mathrm{K}$ & 288 \\
\hline $\begin{array}{l}\text { Air velocity at the inlet of } \\
\text { the heat exchanger }\end{array}$ & $u_{\mathrm{in}, \mathrm{c}}$ & $\mathrm{m} / \mathrm{s}$ & $1 ; 2,4 ; 5$ \\
\hline Inlet turbulence intensity & - & $\%$ & 5 \\
\hline $\begin{array}{l}\text { Internal tube wall } \\
\text { temperature }\end{array}$ & $T_{\mathrm{w}}$ & $\mathrm{K}$ & 353 \\
\hline Outlet pressure & $p_{\text {out,c }}$ & $\mathrm{Pa}$ & 101325 \\
\hline Wall condition & & & $\begin{array}{c}\text { Hydraulically } \\
\text { smooth wall }\end{array}$ \\
\hline
\end{tabular}

Table 4 Output data from Ansys Fluent for $k-\varepsilon$ Realizable with EWT

\begin{tabular}{|l|c|c|c|c|c|}
\hline \multicolumn{1}{|c|}{ turbulence model } \\
\hline \multicolumn{1}{|c|}{ Item } & & & $\begin{array}{c}u_{\text {in,c }}= \\
1,0 \mathrm{~m} / \mathrm{s}\end{array}$ & $\begin{array}{c}u_{\text {in,c }}= \\
2,4 \mathrm{~m} / \mathrm{s}\end{array}$ & $\begin{array}{c}u_{\text {in, }}= \\
5,0 \mathrm{~m} / \mathrm{s}\end{array}$ \\
\hline $\begin{array}{l}\text { Outlet air temp. from } \\
\text { tube bundle }\end{array}$ & $T_{\text {out }}$ & $\mathrm{K}$ & 327,3 & 315,4 & 307,1 \\
\hline $\begin{array}{l}\text { Pressure at the tube } \\
\text { bundle inlet }\end{array}$ & $p_{\text {in }}$ & $\mathrm{Pa}$ & 9,30 & 36,98 & 115,1 \\
\hline $\begin{array}{l}\text { Pressure at the tube } \\
\text { bundle outlet }\end{array}$ & $p_{\text {out }}$ & $\mathrm{Pa}$ & $-1,35$ & $-8,11$ & $-31,13$ \\
\hline
\end{tabular}

Table 5 Output data from Ansys Fluent for $k-\omega$ SST turbulence model

Table 5 Output data from Ansys Fluent for $k-\omega$ SST turbulence model
\begin{tabular}{|l|c|c|c|c|c|}
\hline \multicolumn{1}{|c|}{ Item } & & & $\begin{array}{c}u_{\text {in, }}= \\
1,0 \mathrm{~m} / \mathrm{s}\end{array}$ & $\begin{array}{c}u_{\text {in, }}= \\
2,4 \mathrm{~m} / \mathrm{s}\end{array}$ & $\begin{array}{c}u_{\text {in, }}= \\
5,0 \mathrm{~m} / \mathrm{s}\end{array}$ \\
\hline $\begin{array}{l}\text { Air temp.at tube } \\
\text { bundle outlet }\end{array}$ & $T_{\text {out }}$ & $\mathrm{K}$ & 327,6 & 314,8 & 306,5 \\
\hline $\begin{array}{l}\text { Pressure at the tube } \\
\text { bundle inlet }\end{array}$ & $p_{\text {in }}$ & $\mathrm{Pa}$ & 9,30 & 40,55 & 149,2 \\
\hline $\begin{array}{l}\text { Pressure at the tube } \\
\text { bundle outlet }\end{array}$ & $p_{\text {out }}$ & $\mathrm{Pa}$ & $-1,85$ & $-11,28$ & $-49,85$ \\
\hline
\end{tabular}

\subsection{The results for needle type fins}

The input and output data of the heat calculations are summarized in the tables below.

Table 6 Characteristic dimensions of tube and fins

\begin{tabular}{|l|c|c|c|}
\hline Tube and fin material & - & - & Stainless steel \\
\hline Tube outside diameter & $d_{0}$ & $\mathrm{~mm}$ & 20 \\
\hline Tube inside diameter & $d_{\mathrm{i}}$ & $\mathrm{mm}$ & 17 \\
\hline Tube rows configuration & - & - & staggered \\
\hline Transverse tube pitch & $s_{\mathrm{t}}$ & $\mathrm{mm}$ & 50 \\
\hline Longitudinal tube pitch & $s_{1}$ & $\mathrm{~mm}$ & 40 \\
\hline Fin height & $h_{\mathrm{f}}$ & $\mathrm{mm}$ & 10 \\
\hline Needle root diameter & - & $\mathrm{mm}$ & 27 \\
\hline Number of needle & - & - & 8 \\
\hline Fin thickness & $t_{\mathrm{f}}$ & $\mathrm{mm}$ & 0,5 \\
\hline Fin pitch & $s_{\mathrm{f}}$ & $\mathrm{mm}$ & 4,5 \\
\hline Number of rows & $N_{\mathrm{l}}$ & - & 5 \\
\hline
\end{tabular}

Boundary conditions for needle type fins are the same as for round fins. 
Table 7 Output data from Ansys Fluent for $k-\omega$ SST turbulence model

\begin{tabular}{|l|c|c|c|c|c|}
\hline \multicolumn{1}{|c|}{ Item } & & & $\begin{array}{c}u_{\text {in, }}= \\
1,0 \mathrm{~m} / \mathrm{s}\end{array}$ & $\begin{array}{c}u_{\text {in, }}= \\
2,4 \mathrm{~m} / \mathrm{s}\end{array}$ & $\begin{array}{c}u_{\text {in, }}= \\
5,0 \mathrm{~m} / \mathrm{s}\end{array}$ \\
\hline $\begin{array}{l}\text { Air temp.at tube } \\
\text { bundle outlet }\end{array}$ & $T_{\text {out }}$ & $\mathrm{K}$ & 321,8 & 311,1 & 304,3 \\
\hline $\begin{array}{l}\text { Pressure at the tube } \\
\text { bundle inlet }\end{array}$ & $p_{\text {in }}$ & $\mathrm{Pa}$ & 8,10 & 37,48 & 142,84 \\
\hline $\begin{array}{l}\text { Pressure at the tube } \\
\text { bundle outlet }\end{array}$ & $p_{\text {out }}$ & $\mathrm{Pa}$ & $-2,10$ & $-12,28$ & $-52,52$ \\
\hline
\end{tabular}

\section{Data Reduction and interpretation}

The heat duty is calculated from the calculated mass flow rates and overall temperature changes.

$$
\begin{aligned}
& \dot{m}=\rho_{\text {in }} \cdot A_{\text {tot }} \cdot u_{\text {in }} \\
& Q_{\text {air }}=\dot{m} \cdot c_{\mathrm{p}, \text { av }} \cdot\left(T_{\text {out }}-T_{\text {iu }}\right)
\end{aligned}
$$

To calculate the overall heat transfer coefficient $(U)$, the log-mean (LMTD) method is used.

The logarithmic mean temperature difference for counter-current flow is chosen. According to Næss [17] this method has proven to be accurate to within $0,1 \%$ of the actual cross-counter-current arrangement mean temperature difference.

$$
\Delta T_{\ln }=\frac{T_{\text {in }}-T_{\text {out }}}{\ln \frac{T_{\text {in }}-T_{\mathrm{w}}}{T_{\text {out }}-T_{\mathrm{w}}}}
$$

The overall heat transfer coefficient is then calculated

$$
U=\frac{Q_{\mathrm{air}}}{A \cdot \Delta T_{\ln }}
$$

The effective/apparent air-side heat transfer coefficient is

$$
\left.\alpha_{e}=\frac{1}{\left(\frac{1}{U}-A_{\mathrm{tot}} \frac{\ln \frac{d_{0}}{d_{\mathrm{i}}}}{2 \pi L_{\mathrm{t}} \lambda}-\frac{A_{\mathrm{tot}}}{A_{\mathrm{i}} \alpha_{\mathrm{i}}}\right.}\right)
$$

$L_{\mathrm{t}}$ is tube length that is equal to model width. In the case of air temperatures lower than $300{ }^{\circ} \mathrm{C}$, the value of radiation heat transfer coefficient could be negligible and then its value may be taken as zero. Outside and inside fouling factors are also taken as zero. The effective heat transfer coefficient in Eq. (14) is the apparent heat transfer coefficient including fin efficiency. In order to calculate the actual average gas-side heat transfer coefficient $\alpha_{0}$, the fin efficiency $\eta_{\mathrm{f}}$ is needed.

$$
\alpha_{0}=\frac{\alpha_{\mathrm{e}} \cdot A_{\mathrm{tot}}}{\left(A_{\mathrm{t}}+\eta_{\mathrm{f}} \cdot A_{\mathrm{f}}\right)}
$$

The thermal conductivity of the fin material has a strong effect on the temperature distribution along the fin and therefore influences the degree to which the heat transfer rate is enhanced. In practice, the fin is thin and temperature changes in the transverse direction within the fin are small compared with the temperature difference between the fin and the environment (Fig. 5b).

Ideally, the fin material should have a large thermal conductivity to minimize temperature variations from its base to its tip. In the limit of infinite thermal conductivity, the entire fin would be at the temperature of the base surface, thereby providing the maximum possible heat transfer enhancement. However, since a finite conduction resistance characterizes any fin, a temperature gradient must exist along the fin. In our case, fin material is stainless steel with relative small thermal conductivity 16 $\mathrm{W} /(\mathrm{m} \cdot \mathrm{K})$ and therefore temperature variation in longitudinal direction (Fig. 5b) will be important causing heat transfer less than maximum possible.

In addition, temperature field across fin area is not uniform (Fig. 5a) and temperature of fin tip is different for each needle. All these parameters are taken in account by fin efficiency.
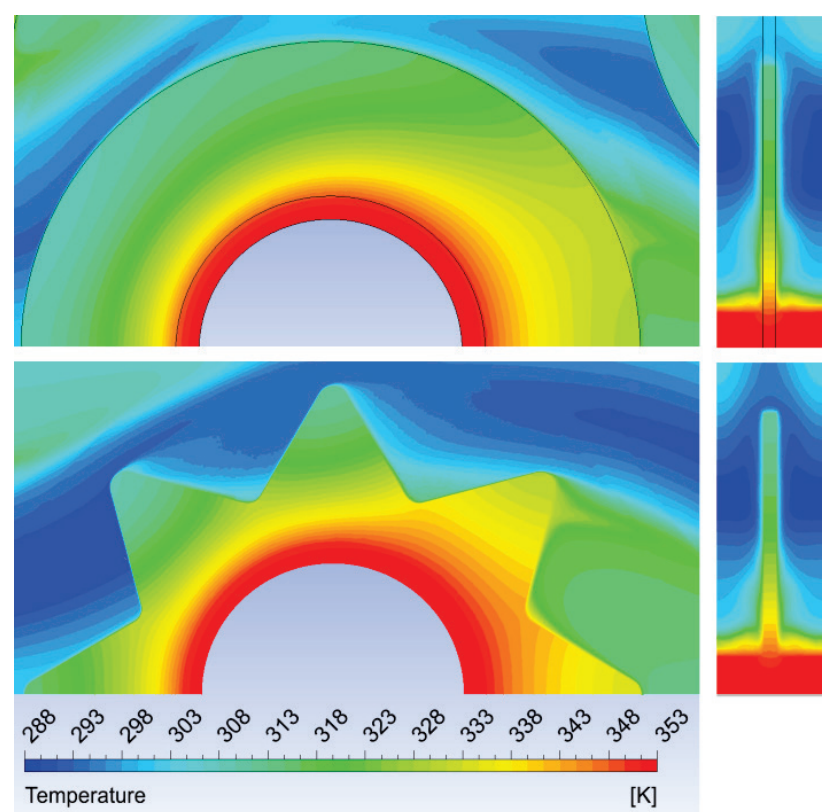

(a)

Figure 5 Temperature over fins in $3^{\text {rd }}$ row for air velocity $5 \mathrm{~m} / \mathrm{s}$

Round fins efficiency is calculated according to Schmidt

$$
\begin{aligned}
& m=\sqrt{\frac{2 \alpha_{0}}{\lambda_{\mathrm{f}} \cdot t_{\mathrm{f}}}} \\
& h_{\mathrm{e}}=h+\frac{t_{\mathrm{f}}}{2}
\end{aligned}
$$

Corrected fin length $h_{\mathrm{e}}$ is based on assumption of equivalence between heat transfer from the actual fin with tip convection and heat transfer from a longer, hypothetical fin with an adiabatic tip.

$$
\begin{aligned}
& \eta_{\mathrm{th}, \mathrm{f}}=\frac{\tanh \left(\psi \cdot m \cdot h_{\mathrm{e}}\right)}{\psi \cdot m \cdot h_{\mathrm{e}}} \\
& \psi=1,0+0,35 \cdot \ln \left(1,0+2,0 \cdot \frac{h_{\mathrm{e}}}{\mathrm{d}_{0}}\right)
\end{aligned}
$$




$$
\begin{aligned}
& E=0,76+0,24 \cdot \eta_{\text {th,f }} \\
& \eta_{\mathrm{f}}=E \cdot \eta_{\text {th,f }}
\end{aligned}
$$

For new type of fins proposed in the article, there is no expression for efficiency in literature. As serrated fins are similar to new type of fins expression for serrated fins will be used. This means some error in calculation and has to be examined in future.

The appropriate theoretical fin efficiency for serrated fins, which compensates for the finite conductance in the fins, under the assumption of a uniform air side heat transfer coefficient, can be expressed as [1]

$$
\eta_{\mathrm{th}, \mathrm{f}}=\frac{\tanh \left(m \cdot h_{\mathrm{e}}\right)}{m \cdot h_{\mathrm{e}}}
$$

where the parameter $m_{\mathrm{e}}$ is given by

$$
\begin{aligned}
& m_{\mathrm{e}}=\sqrt{\frac{2 \alpha_{0}}{\lambda_{\mathrm{f}} \cdot t_{\mathrm{e}}}} \\
& t_{\mathrm{e}}=\frac{t_{\mathrm{f}}}{1+\frac{t_{\mathrm{f}}}{w_{\mathrm{s}}}} \\
& w_{\mathrm{s}}=\frac{d_{\mathrm{r}, \mathrm{f}} \cdot \pi}{2 \cdot N_{\mathrm{n}}}
\end{aligned}
$$

where $w_{\mathrm{s}}$ is average width of needle fin and $t_{\mathrm{e}}$ is equivalence thickness of fin, $d_{\mathrm{r}, \mathrm{f}}$ is root diameter of fin needle.

Due to the formation of vortices and boundary layers, the assumption of uniformity of heat transfer coefficient across the fin does not hold in actual situations. Experiments have shown lower heat transfer coefficients than predicted theoretically. In the present analysis for needle type fins an empirical correction factor to the theoretical fin efficiency proposed by Weierman [5] for serrated fins is used.

$$
E=0,9+0,1 \cdot \eta_{\mathrm{th}, \mathrm{f}}
$$

Efficiency of serrated fins is defined acc. to Eq. 21.

Recall that fins are used to increase the heat transfer from a surface by increasing the effective surface area. However, the fin itself represents a conduction resistance to heat transfer from the base surface. For this reason, there is no assurance that the heat transfer rate will be increased by the use of fins. An assessment of this matter may be done by evaluating the fin effectiveness $\varepsilon_{f}$.

Both the fin efficiency and fin effectiveness are related to the performance of the fin, but they are different quantities. However, they are related to each other by

$\varepsilon_{\mathrm{f}}=\frac{A_{\mathrm{f}}}{A_{\mathrm{t}}} \cdot \eta_{\mathrm{f}}$

Numerical pressure drop in tube bundle is calculated from the next expression
$\Delta p=p_{\text {in }}-p_{\text {out }}$

where $p_{\text {in }}$ and $p_{\text {out }}$ is the mass weighted average pressure at inlet and outlet of tube bundle (see Fig. 2).

\section{$5 \quad$ Validation with literature results for round fins}

Flow through tube banks is studied experimentally since it is too complex to be treated analytically. Engineers are primarily interested in the average heat transfer coefficient for the entire tube bank, which depends on the number of tube rows along the flow as well as the arrangement and the geometry of the tubes and fins. Several correlations from literature, all based on experimental data, have been proposed for the average Nusselt number for cross flow over tube banks with round fins.

For the validation of selected turbulence models, a comparison of the $N u$ and $E u$ obtained by heat calculation for the described model and calculation by correlation with Briggs [9], ESDU [35], VDI-Warmeatlas [33], D. J. Ward and E. H. Young [3], T. E. Schmidt [23], PFR [36] and Feten [37].

It should be noted that in most cases the correlations that define $N u$ number do not specify whether the physical properties of the fluid should be selected for the boundary layer or for the bulk flow. For the evaluation of $N u$ number in this article, physical properties of the fluid boundary layer are taken. This can potentially make a certain error in the results. In Fig. 6 to Fig. 9 there is a comparison of the calculation results of the analysed model with round fins and the results obtained by correlations from the literature.

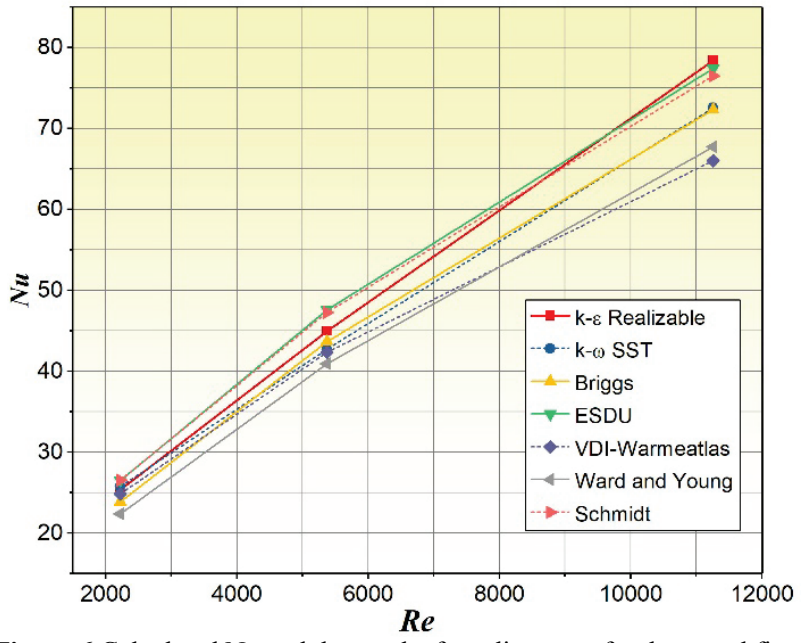

Figure 6 Calculated $\mathrm{Nu}$ and the results from literature for the round fins

The values of $N u$ numbers obtained on the SST $k$ - $\omega$ turbulence model show max. deviation of $13 \%$ according to the reference correlations which can be evaluated as very good (Fig. 7).

$E u$ values for the SST k- $\omega$ turbulence model show slightly greater deviation from literature. The deviations are higher for lower $R e$ values and up to $29 \%$ while for higher values of $R e$ deviations are up to $16 \%$ (Fig. 9). Also, the values of $E u$ are less than by correlations. Interestingly, the $\mathrm{k}-\varepsilon$ Realizable model shows a better trend of results than the SST k- $\omega$ model in the observed 
range of $R e$ compared to the literature although the deviations are higher.

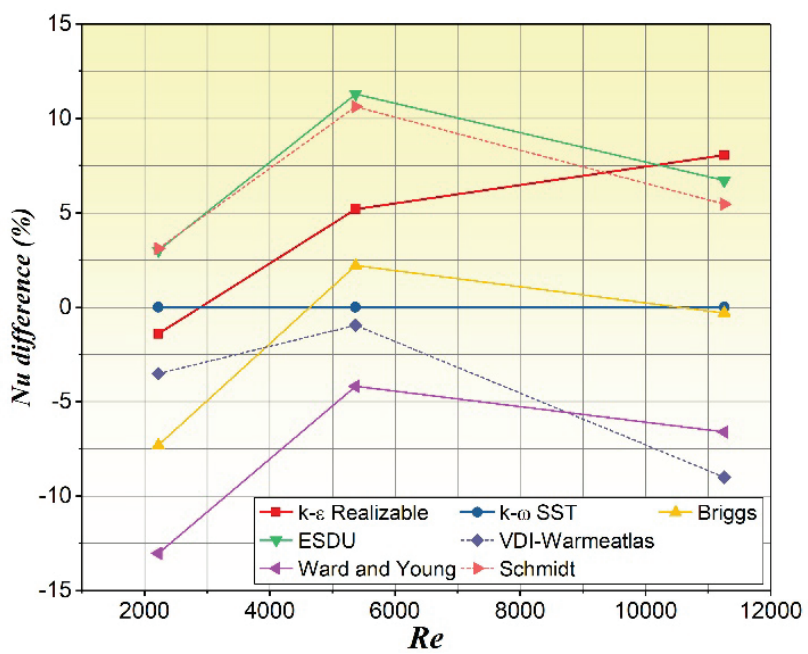

Figure 7 The difference between the computed $N u$ and the results from the literature

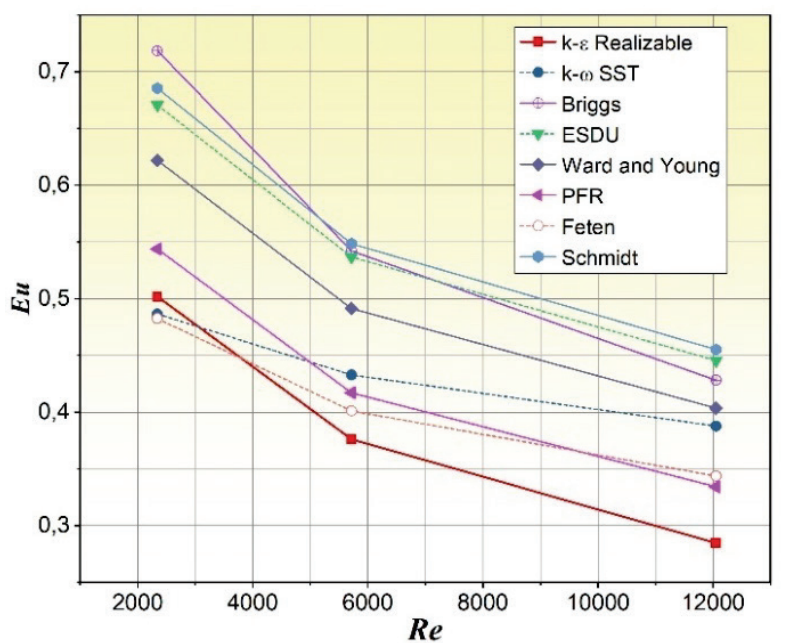

Figure 8 Calculated $E u$ and the results from literature for the round fins

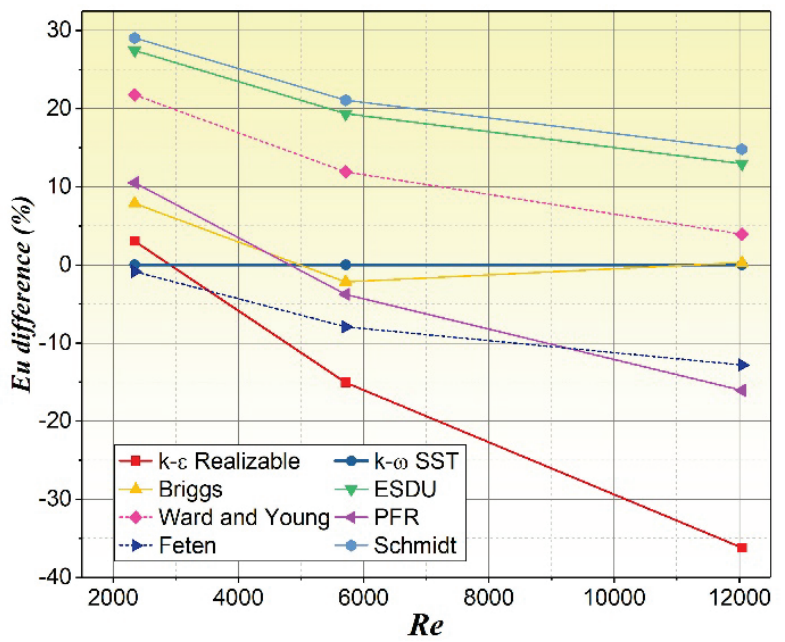

Figure 9 The difference between the computed $E u$ and the results from the literature

From the previous diagrams, it can be seen that the SST $k-\omega$ model of turbulence in the observed area of $R e$ numbers shows a better match to the results of literature than the $k-\varepsilon$ Realizable model.
In accordance with the previously discussed for further comparison of the round fins and the new type of needle fins, the SST $k-\omega$ turbulence model will be selected.

\section{Comparison of calculation results for round fins and needle type fins}

\subsection{Flow characteristic}

The global velocity distribution in the bundle is essential for understanding the local flow and heat transfer phenomena. Fig. 10 shows velocity fields in a cross-section passing through the middle of fin thickness.

Figs. 9, 10,11 and 12 show the local characteristics of the temperature, pressure, turbulent kinetic energy and the air speed of the needle type finned exchanger and round finned exchanger for inlet air velocity of $5,0 \mathrm{~m} / \mathrm{s}$. Cross flow over a tube exhibits complex flow patterns. The fluid approaching the tube branches out and encircles the tube, forming a boundary layer that wraps around the tube. The fluid particles on the mid-plane strike the tube at the stagnation point, bringing the fluid to a complete stop and thus raising the pressure at that point. The pressure decreases in the flow direction while the fluid velocity increases. Fluid embraces the tube on the frontal side, but it is too fast to remain attached to the surface as it approaches the top of the tube. As a result, the boundary layer detaches from the surface at approximately $120^{\circ}$, forming a separation region behind the tube. Flow in the wake region and especially after the $5^{\text {th }}$ row of tubes is characterized by vortex formation and pressures much lower than the stagnation point pressure. Caused by the slower air flow, higher temperatures persisted in wake areas.

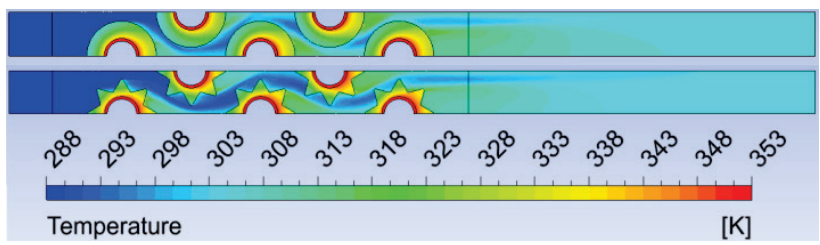

Figure 10 Temperature fields comparison of round and needle type fins

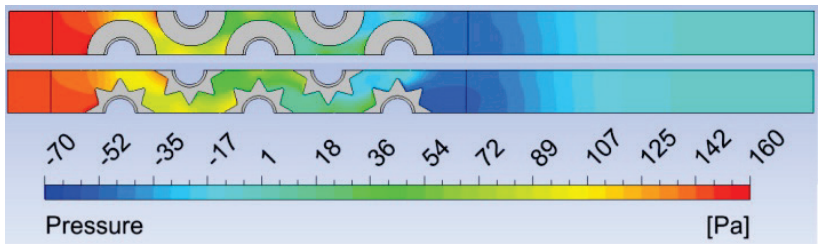

Figure 11 Pressure fields comparison of round and needle type fins

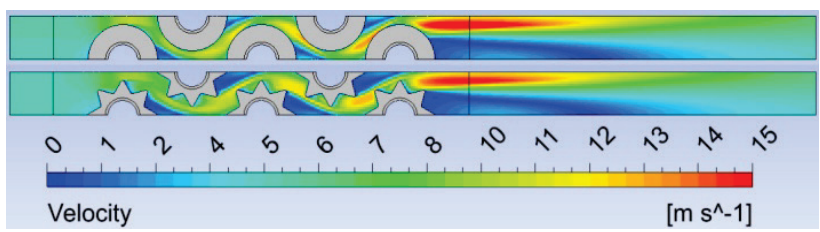

Figure 12 Velocity fields comparison of round and needle type fins

The difference in the air velocity field (Fig. 12) and the level of turbulence, and thus the difference in heat transfer coefficient increases with row number because of the combined effects of upstream rows. In the case of a needle shaped fins, the formation of the vortex is more 
emphasized than in the case of round fins. It is also apparent that the amount of turbulence energy is greater for the needle shape fins (Fig. 13).

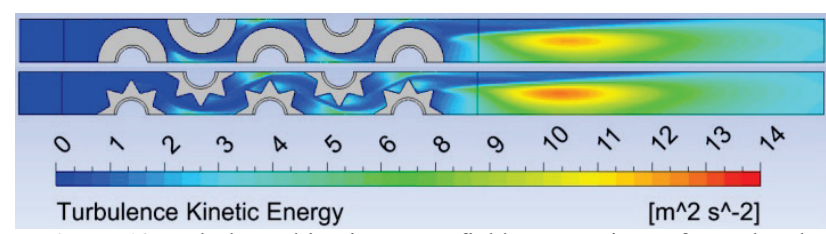

Figure 13 Turbulence kinetic energy fields comparison of round and needle type fins

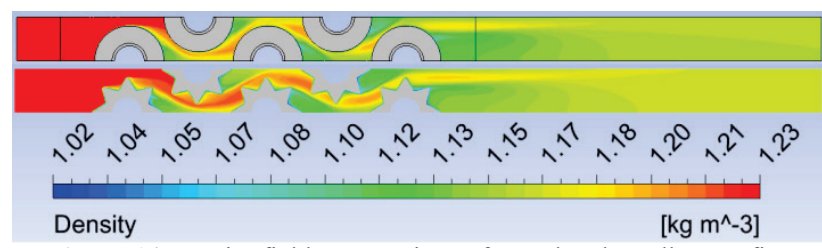

Figure 14 Density fields comparison of round and needle type fins

To ensure accuracy in calculating the thermal boundary layer, the low-Re approach to modelling the near-wall flow was used. Consequently, the near-wall mesh resolution places nodes within the viscous sublayer, avoiding reliance on a wall function. Accordingly, on fluid-side the wall-adjacent mesh spacing $(\Delta y)$ was sufficiently small so that $y^{+}<1$ at the fin and tube surfaces. For inlet air velocity $1 \mathrm{~m} / \mathrm{s}$ and $2,4 \mathrm{~m} / \mathrm{s} \max$. value of $y^{+}$is 1,0 . For nominal velocity $5 \mathrm{~m} / \mathrm{s}$ on the largest part of the surface $y^{+}$is less than 1 and in a small part of the surface reaches a value of 1,8 (Fig.15). SST $k$ $\omega$ model switches automatically from a wall function to a low-Re formulation, based on the grid density provided by the user. It ensures therefore an optimal accuracy of the CFD solution on a given grid and allows the use of coarser near-wall grids, which also benefits the cell aspect ratio.

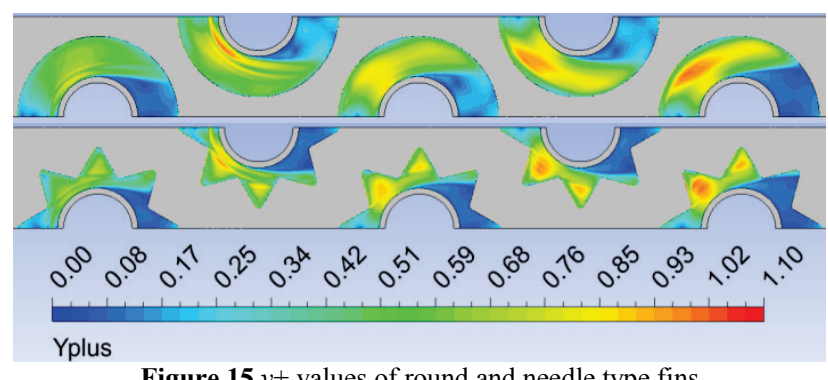

In general, it can be concluded that the two types of fins have substantially similar flow characteristics but turbulence is somewhat higher for needle type fins that results in better heat transfer.

\subsection{Non-dimensional numbers $N u$ and $E u$}

The numerical results of the calculation based on the data given in Tab. 5 and Tab. 7 can be graphically displayed.

As can be seen from Fig. 16 and Fig. 17, Nu number is greater than $20 \%$ to $30 \%$ for needle type fins compared to $N u$ number for round fins. The difference is more significant for higher Re numbers. In the analysis of finned heat exchanger with segmented fins R. Hofmann
[24] stated the average increase in the $N u$ number of $22 \%$ relative to the finned exchanger with circular round fins. In our case, increase in $N u$ number is higher and it is around $26 \%$.

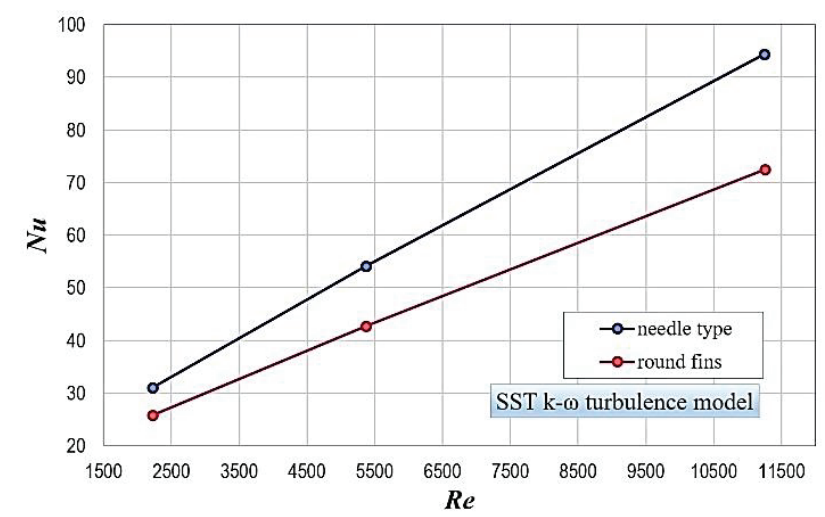

Figure 16 Computational $N u$ results for round and needle type fins

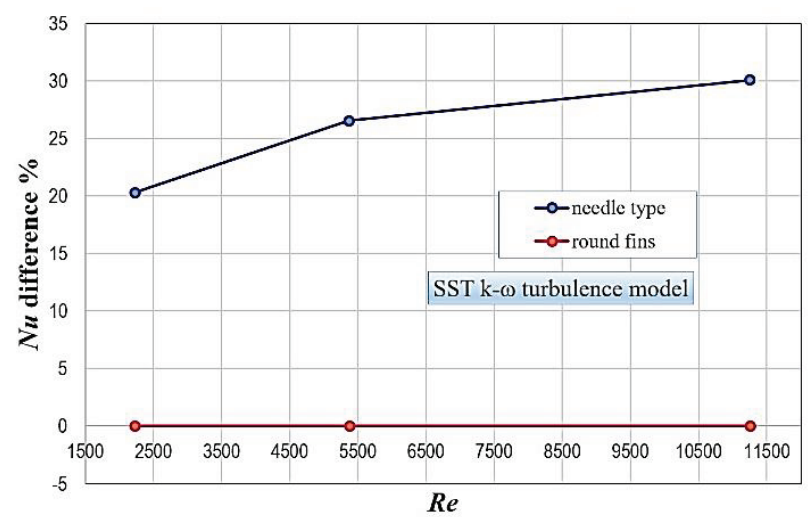

Figure $17 \mathrm{Nu}$ difference between round and needle type fins

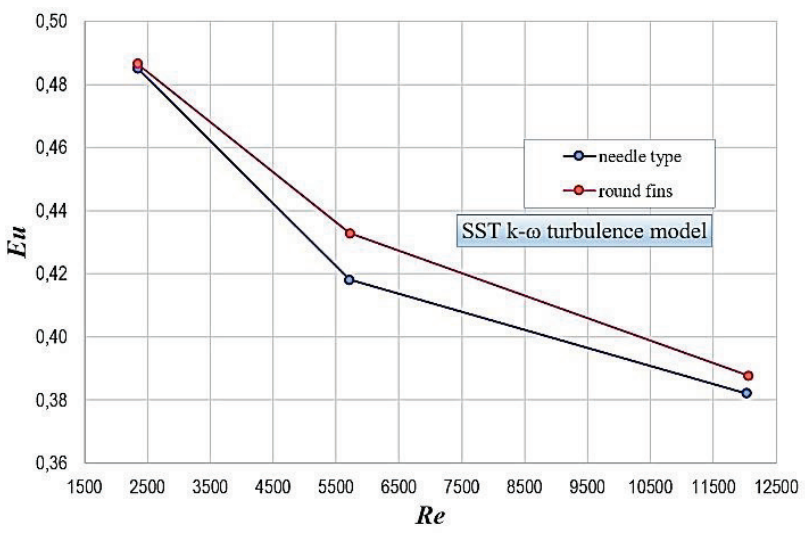

Figure 18 Computational $E u$ results for round and needle type fins

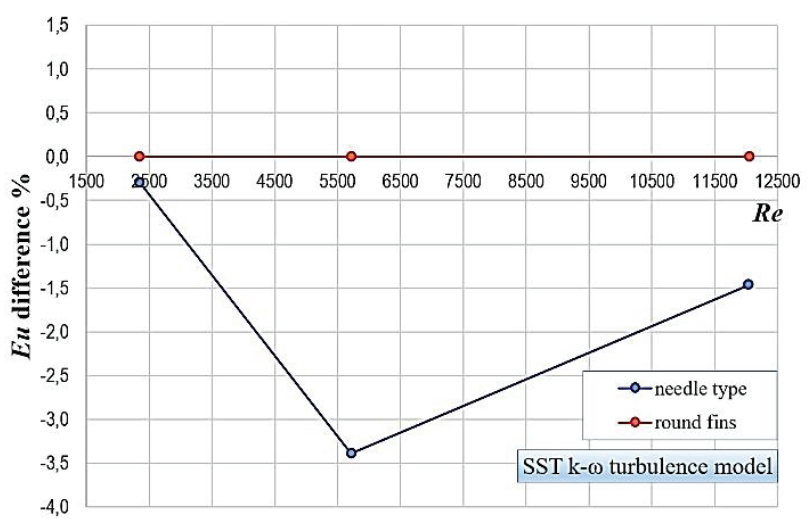

Figure $19 \mathrm{Eu}$ difference between round and needle type fins 
Fig. 18 and Fig. 19 show that $E u$ number is approximately equal for both fin types. Even for the needle type fin $E u$ decreases a little with its value. Although the fin shape varies the net free area in a tube row is nearly the same in both cases. Thus, a significant difference among pressure drop is not expected.

\subsection{Performance assessment}

The performance rating of the two observed heat exchangers will be analysed through multiple parameters. The efficiency and effectiveness of round fin and needle type fin are analysed first. It is evident that round fin has a much greater effectiveness of needle type fin proportionally larger surface. The efficiency of the round fin is also greater than needle type fin efficiency, meaning that the temperature difference is smaller between the fin root and fin tip. For a given material and flow conditions it actually means lower heat exchange which is evident from Fig. 22 and Fig. 23.

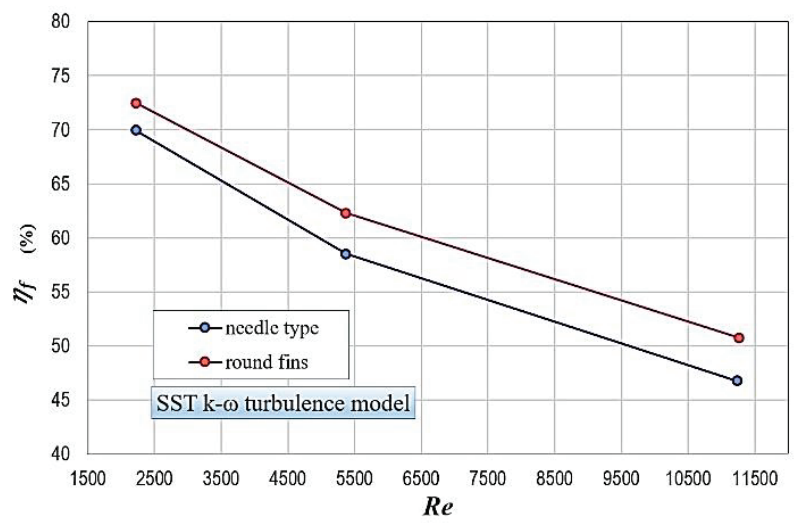

Figure 20 Fin efficiency

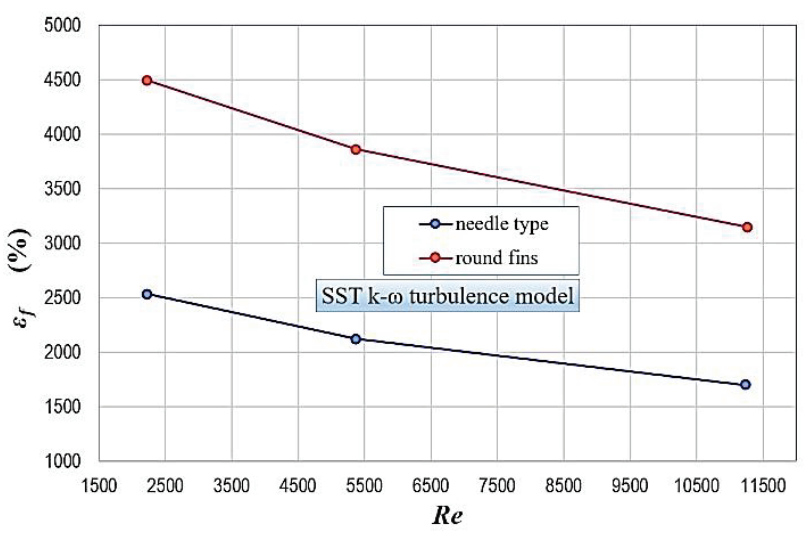

Figure 21 Fin effectiveness

The exchanged heat per unit of heat exchanger surface area is higher for the needle type fins by $35 \%$ at $R e=2340$ and $39,3 \%$ at $R e=12000$.

The power required to keep a fluid flowing through the tube bank (and thus the operating cost) is proportional to the pressure drop. Therefore, the benefits of enhancing heat transfer via fins should be weighed against the cost of fan power requirements. Specific fan power can be defined as

$e_{\mathrm{s}, \mathrm{fan}}=\frac{\dot{m} \cdot \Delta p}{Q_{\mathrm{air}} \cdot \rho_{\text {in }} \cdot \eta_{\mathrm{fan}}}$
Specific fan power is about $10 \%$ greater for needle type fins than round fins.

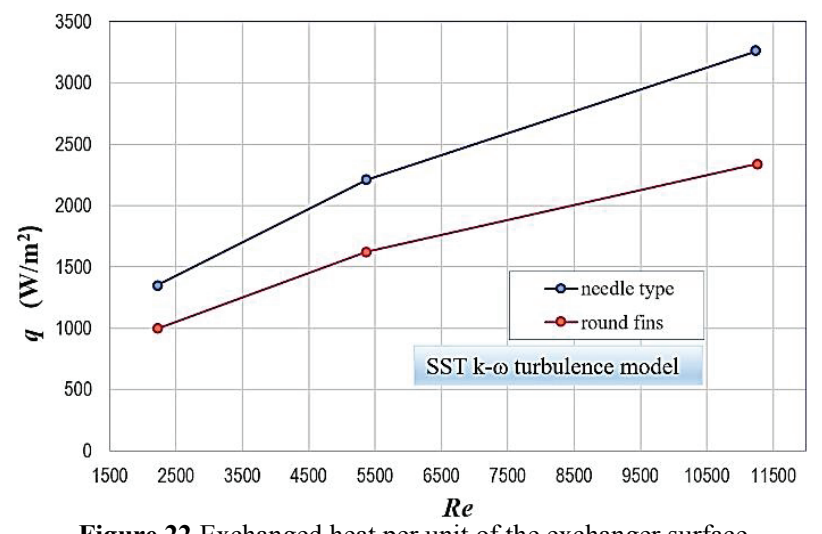

Figure 22 Exchanged heat per unit of the exchanger surface

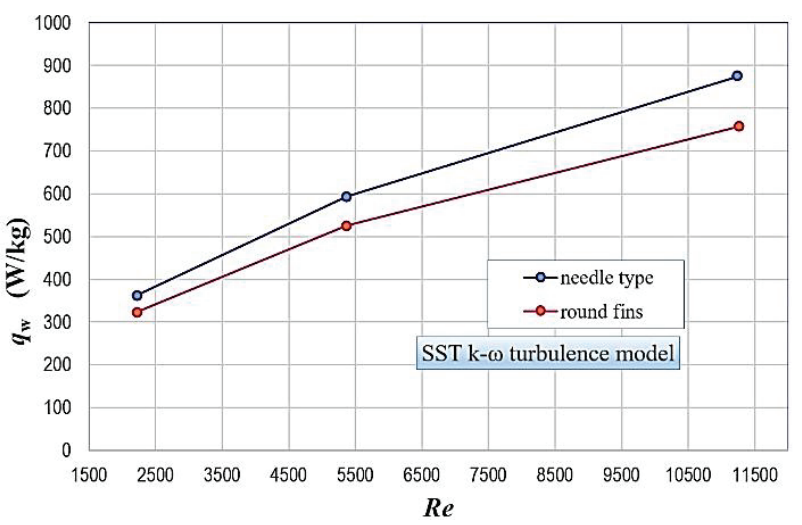

Figure 23 Exchanged heat per unit of mass of exchanging surfaces

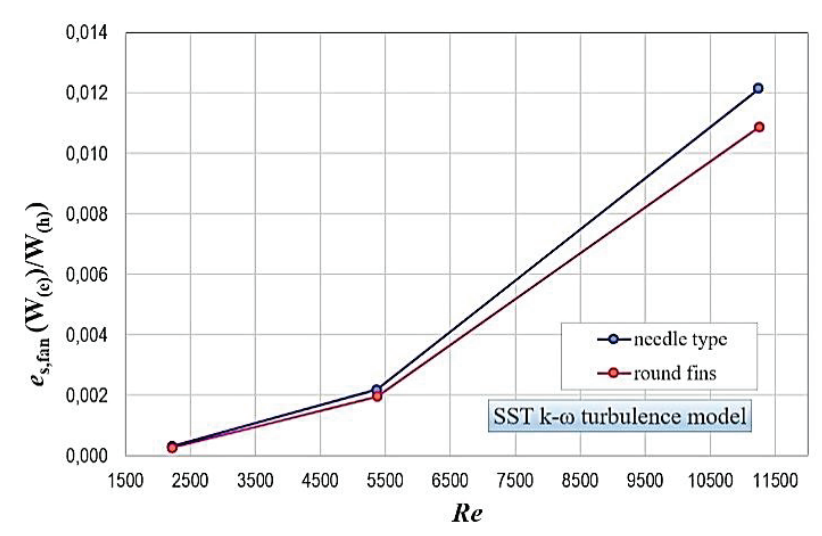

Figure 24 Specific fan power

\section{Conclusion}

Numerical simulations of heat exchanger with needle type fins and round fins were performed in the same way, under the same initial assumptions and parameters applying two turbulence models. Comparing data obtained from CFD and data from literature, SST k- $\omega$ turbulence model was selected. For the selected turbulence model and air input speeds of 1,0;2,4 and 5,0 $\mathrm{m} / \mathrm{s}$, a comparison was made between the $N u$ and $E u$ numbers for round fins and needle fins. The needle fins showed better results in terms of increasing the $N u$ number to $30 \%$ while simultaneously reducing the weight of the exchange surfaces by $23,8 \%$. Increase in the required specific fan power for the operation of exchanger with needle type is about $10 \%$. On the other side, round 
fins are more effective, primarily because of the larger surface for heat exchange.

The variance of the fin geometry, the fin pitch and the tube pitch will be the subject of the next research to give a more complete picture of the new needle type fin.

\section{Nomenclature}

\begin{tabular}{|c|c|c|}
\hline$A$ & surface area & $\mathrm{m}^{2}$ \\
\hline$A_{\mathrm{f}}$ & fin surface area & $\mathrm{m}^{2}$ \\
\hline$A_{\mathrm{ff}}$ & min. free flow area in a tube row & $\mathrm{m}^{2}$ \\
\hline$A_{\mathrm{t}}$ & $\begin{array}{l}\text { tube outside surface area except } \\
\text { fins }\end{array}$ & $\mathrm{m}^{2}$ \\
\hline$A_{\text {tot }}$ & total heat transfer area on air side & $\mathrm{m}^{2}$ \\
\hline$c_{\mathrm{p}, \mathrm{av}}$ & air specific heat capacity for $T_{\mathrm{av}}$ & $\mathrm{J} /(\mathrm{kg} \cdot \mathrm{K})$ \\
\hline$d_{\mathrm{i}}$ & inside tube diameter & $\mathrm{mm}$ \\
\hline$d_{\mathrm{o}}$ & Outside tube diameter & $\mathrm{mm}$ \\
\hline$d_{\mathrm{r}, \mathrm{f}}$ & root diameter of fin needle & $\mathrm{mm}$ \\
\hline$e$ & total specific energy & $\mathrm{J} / \mathrm{kg}$ \\
\hline E & $\begin{array}{l}\text { empirical correction factor to the } \\
\text { theoretical fin efficiency for } \\
\text { serrated fins }\end{array}$ & - \\
\hline$E u$ & Euler number & - \\
\hline ESDU & $\begin{array}{l}\text { Engineering Sciences Data Unit, } \\
\text { United Kingdom }\end{array}$ & - \\
\hline$f_{\mathrm{i}}$ & $\begin{array}{l}\text { vector of mass density of the } \\
\text { external forces }\end{array}$ & $\mathrm{N} / \mathrm{kg}$ \\
\hline$h_{\mathrm{f}}$ & fin height & $\mathrm{mm}$ \\
\hline$h_{\mathrm{e}}$ & fin height & $\mathrm{mm}$ \\
\hline$L_{\mathrm{t}}$ & tube length (equal to model width) & $\mathrm{mm}$ \\
\hline$m$ & $\begin{array}{l}\text { fin effectiveness parameter for } \\
\text { round fins }\end{array}$ & - \\
\hline$m_{\mathrm{e}}$ & $\begin{array}{l}\text { fin effectiveness parameter for } \\
\text { serrated fins }\end{array}$ & - \\
\hline$\dot{m}$ & air mass flow & $\mathrm{kg} / \mathrm{s}$ \\
\hline$N_{1}$ & $\begin{array}{l}\text { number of tubes in the flow } \\
\text { direction }\end{array}$ & - \\
\hline$N_{\mathrm{n}}$ & number of needles of fin & - \\
\hline $\mathrm{Nu}$ & Nusselt number & - \\
\hline$p_{\text {in }}$ & $\begin{array}{l}\text { mass weighted average pressure at } \\
\text { inlet of tube bundle }\end{array}$ & $\mathrm{Pa}$ \\
\hline$p_{\text {out }}$ & $\begin{array}{l}\text { mass weighted average pressure } \\
\text { outlet of tube bundle }\end{array}$ & $\mathrm{Pa}$ \\
\hline$p_{\text {out }, \mathrm{c}}$ & $\begin{array}{l}\text { mass weighted average pressure } \\
\text { outlet of channel }\end{array}$ & $\mathrm{Pa}$ \\
\hline$\Delta p$ & pressure drop & $\mathrm{Pa}$ \\
\hline $\operatorname{Pr}$ & Prandtl number & - \\
\hline$Q$ & heat flow rate & $\mathrm{W}$ \\
\hline$q$ & heat flux vector & $\mathrm{W}$ \\
\hline $\operatorname{Re}$ & Reynolds number & - \\
\hline$s_{\mathrm{f}}$ & fin pitch & $\mathrm{mm}$ \\
\hline$s_{1}$ & longitudinal tube pitch & $\mathrm{mm}$ \\
\hline$s_{\mathrm{t}}$ & transverse tube pitch & $\mathrm{mm}$ \\
\hline$T_{\mathrm{av}}$ & $\begin{array}{l}\text { mean air temperature in tube } \\
\text { bundle }\end{array}$ & $\mathrm{K}$ \\
\hline$T_{\mathrm{bl}}$ & $\begin{array}{l}\text { film temperature - boundary layer } \\
\text { temperature }\end{array}$ & $\mathrm{K}$ \\
\hline$t_{\mathrm{e}}$ & equivalence thickness of fin & $\mathrm{mm}$ \\
\hline$t_{\mathrm{f}}$ & fin thickness & $\mathrm{mm}$ \\
\hline$t$ & time & s \\
\hline$T_{\text {in }}$ & air inlet temperature & $\mathrm{K}$ \\
\hline$T_{\text {out }}$ & air outlet temperature & $\mathrm{K}$ \\
\hline$T_{\mathrm{w}}$ & tube wall temperature & $\mathrm{K}$ \\
\hline
\end{tabular}

\begin{tabular}{|c|c|c|}
\hline$U$ & overall heat transfer coefficient & $\mathrm{W} /\left(\mathrm{m}^{2} \cdot \mathrm{K}\right)$ \\
\hline$u_{\mathrm{ff}}$ & velocity at minimum flow area & $\mathrm{m} / \mathrm{s}$ \\
\hline$u_{\text {in }}$ & air velocity at the inlet of tube bundle & $\mathrm{m} / \mathrm{s}$ \\
\hline$u_{\text {in, } \mathrm{c}}$ & $\begin{array}{l}\text { air velocity at the inlet of the heat } \\
\text { exchanger }\end{array}$ & $\mathrm{m} / \mathrm{s}$ \\
\hline$w_{\mathrm{s}}$ & average width of needle fin & $\mathrm{mm}$ \\
\hline$\alpha_{0}$ & $\begin{array}{l}\text { actual average gas-side heat } \\
\text { transfer coefficient }\end{array}$ & $\mathrm{W} /\left(\mathrm{m}^{2} \cdot \mathrm{K}\right)$ \\
\hline$\alpha_{\mathrm{e}}$ & $\begin{array}{l}\text { effective heat transfer coefficient } \\
\text { based on total fin side surface area }\end{array}$ & $\mathrm{W} /\left(\mathrm{m}^{2} \cdot \mathrm{K}\right)$ \\
\hline$\Delta T_{\ln }$ & $\begin{array}{l}\text { logarithmic mean temperature } \\
\text { difference (LMTD) }\end{array}$ & $\mathrm{K}$ \\
\hline$\varepsilon_{\mathrm{f}}$ & fin effectiveness & - \\
\hline$\eta_{\mathrm{f}, \mathrm{th}}$ & theoretical fin efficiency & - \\
\hline$\lambda_{\mathrm{bl}}$ & $\begin{array}{l}\text { thermal conductivity of boundary } \\
\text { layer at } T_{b l}\end{array}$ & $\mathrm{~W} /(\mathrm{m} \cdot \mathrm{K})$ \\
\hline$\lambda_{\mathrm{f}}$ & $\begin{array}{l}\text { thermal conductivity of fin } \\
\text { material }\end{array}$ & $\mathrm{W} /(\mathrm{m} \cdot \mathrm{K})$ \\
\hline$\lambda_{\mathrm{t}}$ & $\begin{array}{l}\text { thermal conductivity of tube } \\
\text { material }\end{array}$ & $\mathrm{W} /(\mathrm{m} \cdot \mathrm{K})$ \\
\hline$\mu_{\mathrm{av}}$ & air average kinematic viscosity & $\mathrm{m}^{2} / \mathrm{s}$ \\
\hline$\rho_{\mathrm{av}}$ & air average density (at $T_{\mathrm{av}}$ ) & $\mathrm{kg} / \mathrm{m}^{3}$ \\
\hline$\rho_{\text {in }}$ & air density at inlet (at $T_{\text {in }}$ ) & $\mathrm{kg} / \mathrm{m}^{3}$ \\
\hline$\sigma_{\mathrm{ij}}$ & tensor of stress in fluid & $\mathrm{Pa}$ \\
\hline
\end{tabular}

\section{References}

[1] Hashizume, K.; Matsue, T. Fin Efficiency of Serrated Fins: Part 1. Analysis of Theoretical Fin Efficiency and Experimental Results. // Heat Transfer-Asian Research. 28, 6(1999), pp. 528-540. https://doi.org/10.1002/(SICI)15231496(1999)28:6<528::AID-HTJ9>3.0.CO;2-B

[2] Kays, W. M.; London, A. L. Compact Heat Exchangers, McGraw-Hill, New York, 1964.

[3] Ward, D. J.; Young, E. H. Heat transfer and pressure drop of air in forced convection across triangular pitch banks of finned tubes. // Chem. Eng. Prog. Symp. Ser. 55, 29(1959), pp. 37-44.

[4] Kearney, S. P.; Jacobi, A. M. Local Convective Behavior and Fin Efficiency in Shallow Banks of Inline and Staggered, Solidly Finned Tubes. // ASME Journal of Heat Transfer. 118, (1996), pp. 317-326. https://doi.org/10.1115/1.2825847

[5] Weierman, C. Correlations ease the selection of finned tubes. // The Oil and Gas Journal. 74, 36(1976), pp. 94-100.

[6] Frasz, F. Waermeuebertragung in Rippenrohrwaerme austauschern.// Waermeaustauscher, Energieeinsparung durch Optimierung von Waermeprozessen, Vulkan-Verlag Essen. 2(1994), pp. 70-76.

[7] Kawaguchi, K. Heat transfer and pressure drop characteristics of finned tube banks in forced convection. // Journal of Enhanced Heat Transfer. 12, 1(2005), pp. 1-20. https://doi.org/10.1615/JEnhHeatTransf.v12.i1.10

[8] Halici, F.; Taymaz, I. Experimental study of the airside performance of tube row spacing in finned tube heat exchangers. // Heat and Mass Transfer. 42(2006), pp. 817822. https://doi.org/10.1007/s00231-005-0042-1

[9] Briggs, D. E.; Young, E. H. Convection Heat Transfer and Pressure Drop of Air Flowing Across Triangular Pitch Banks of Finned Tubes. // Chem.-Ing. Technik. 33, 6(1963), pp. 431-438.

[10] Reid, D. R.; Taborek, J. Selection criteria for plain and segmented finned tubes for heat recovery systems. // Transactions of the ASME. 116 (1994), pp. 406-410. https://doi.org/10.1115/1.2906835

[11] Weierman, C., Taborek, J.; Marner, W. J. Comparison of the performance of in-line and staggered banks of tubes 
with segmented fins. // The American Institute of Chem. Engineers. 74, 174(1978), pp. 39-46.

[12] Chapter 14. // High-Performance Single-Phase Heat Exchangers // Zhukauskas, A. New York: Hemisphere Publishing, 1989.

[13] Stasiulevičius, J.; Skrinska, A. Heat Transfer of Finned Tube Bundles in Crossflow, New York: Hemisphere Publishing, 1988, ISBN 3-540-18211-x

[14] Sandar M. M.; Gross, U. Numerical study of fin-spacing effects in solid-finned tube heat exchangers. // International Journal of Heat and Mass Transfer. 47(2004), pp. 19531964. https://doi.org/10.1016/j.ijheatmasstransfer.2003.09.034

[15] Ali Shakir A. J.; Majid H. M.; Bassam A. S. Circular fins with slanted blades attached on the copper pipe: Uniform heat flux and isothermal processes. // International Journal of Mechanical Engineering and Technology (IJMET). 5, 5(2014), pp. 133-143.

[16] Lemouedda, A.; Schmid, A.; Franz, E.; Breuer, M.; Delgado, A. Numerical investigations for the optimization of serrated finned-tube heat exchangers. // Applied Thermal Engineering. 31(2011), pp. 1393-1401. https://doi.org/10.1016/j.applthermaleng.2010.12.035

[17] Næss, E. Experimental investigation of heat transfer and pressure drop in serrated-fin tube bundles with staggered tube layouts. // Applied Thermal Engineering. 30(2010), pp. 1531-1537. https://doi.org/10.1016/j.applthermaleng.2010.02.019

[18] Martinez, E.; Vicente, W.; Soto, G.; Salinas, M. Comparative analysis of heat transfer and pressure drop in helically segmented finned tube heat exchangers. // Applied Thermal Engineering. 30(2010), pp. 1470-1476. https://doi.org/10.1016/j.applthermaleng.2010.03.007

[19] Cathal Cléirigh, T. Ó.; Smith, W. J. Can CFD accurately predict the heat-transfer and pressure-drop performance of finned-tube bundles? // Applied Thermal Engineering. 73, 1(2014), pp. 681-690. https://doi.org/10.1016/j.applthermaleng.2014.08.019

[20] Anoop, B.; Balaji, C.; Velusamy, K. A characteristic correlation for heat transfer over serrated finned tubes. // Annals of Nuclear Energy. 85(2015), pp. 1052-1065. https://doi.org/10.1016/j.anucene.2015.07.025

[21] Hofmann, R.; Frasz, F.; Ponweiser, K. Heat Transfer and Pressure Drop Performance Comparison of Finned-Tube Bundles in Forced Convection. // Wseas transactions on heat and mass transfer. 4, 2(2007), ISSN: 1790-5044

[22] Briggs, D. E.; Young E. H. Convection heat transfer and pressure drop of air flowing across triangular pitch banks of finned tubes. // Chem. Eng. Prog. Symp. Ser. 59, No. 41, 1963, pp. 1-10.

[23] Schmidt, T. E. Verbesserte Methoden zur Bestimmung des Wärmeaustausches an berippten Flächen. // KältetechnikKlimatisierung. 18(1966), pp. 135-138.

[24] Ward D. J.; Young, E. H. Heat transfer and pressure drop of air in forced convection across triangular pitch banks of finned tubes. // Chem. Eng. Prog. Symp. Ser. 55, 29(1959), pp. 37-44.

[25] Nir, A. Heat Transfer and Friction Factor Correlations for Cross Flow Over Staggered Finned Tube Banks. // Heat Transfer Engineering. 12, 1(1991), pp. 43-58 https://doi.org/10.1080/01457639108939746

[26] Lokman, H. M.; Fdhila, R. B. Literature Review of accelerated CFD Simulation Methods towards Online Application. // Energy Procedia 75(2015), pp. 3307-3314. https://doi.org/10.1016/j.egypro.2015.07.714

[27] Hossain, N.; Moghimi, M. Numerical Study of Flow Over Solid-Finned Tube Heat Exchangers by Different Turbulent Models. // CFD Letters, 6, 3(2014).

[28] Rabas, T. J.; Taborek, J. Survey of Turbulent ForcedConvection Heat Transfer and pressure Drop Characteristics of Low-Finned Tube Banks in Cross Flow. // Heat Transfer Engineering. 8, 2(1987), pp. 49-62. https://doi.org/10.1080/01457638708962793

[29] Kuntysh, V. B.; Iokhvedov, F. M. Heat Transfer. // Soviet Research. 3(1971), pp. 50-61.

[30] Pongsoi, P.; Wongwises, S. Determination of fin pitches for maximum performance index of l-footed spiral fin-and-tube heat exchangers. // Journal of Thermal Engineering, Yildiz Technical University Press, Istanbul. 1, Special Issue 1(2015), pp. 251-262.

[31] Halici, F.; Taymaz, I. Experimental study of the airside performance of tube row spacing in finned tube heat exchangers. // Heat and Mass Transfer, 42(2006), pp. 817822. https://doi.org/10.1007/s00231-005-0042-1

[32] Incropera, F. P.; DeWitt, D. P.; Bergman, T. L.; Lavine, A. S. Fundamentals of Heat and Mass Transfer. John Wiley \& Sons, Inc., 2007.

[33] Verein Deutscher Ingenieure, VDI-Wärmeatlas, Berechnungsblätter feur den Wärmeübergang, 8. Aufl. Berlin u.a., Springer, 2000.

[34] Yunus, Ç. A. Heat Transfer: A Practical Approach. $2^{\text {nd }}$ ed, New York: McGraw-Hill, 2004.

[35] ESDU 1986. 86022: High-fin Staggered Tube Banks: Heat Transfer and Pressure Drop for Turbulent Single Phase Gas Flow. Engineering Sciences Data Unit, United Kingdom.

[36] PFR Engineering Systems, Inc.: Heat Transfer and Pressure Drop Characteristics of Dry Tower Extended Surfaces. Battelle Memorial Institute, 1976.

[37] Feten, T. G. F. Multivariate analysis of heat transfer and pressure drop in finned tube bundles. Master Thesis, 2013.

\section{Authors' addresses}

Mladen Bošnjaković, M.Sc. College of Slavonski Brod, Dr. M. Budaka 1,

35000 Slavonski Brod, Croatia mladen.bosnjakovic@vusb.hr

\section{Ante Čikić, Ph.D. Associate Prof. \\ Technical College in Bjelovar, \\ Trg Eugena Kvaternika 4, 43000 Bjelovar, Croatia acikic@vtsbj.hr}

Simon Muhič, Ph.D., Associate Prof.

Faculty of Technologies and Systems, Na Loko 2,

8000 Novo mesto, Slovenia

simon.muhic@fts-nm.si

\section{Marinko Stojkov, Ph.D., Full Prof.}

Mechanical Engineering Faculty in Slavonski Brod,

Trg Ivane Brlić Mažuranić 2,

35000 Slavonski Brod, Croatia

mstojkov@sfsb.hr 